\title{
РОЛЬ МОВИ У КОНТЕКСТІ ІДЕНТИЧНОСТІ ТА АКУЛЬТУРАЦІЇ МІГРАНТІВ
}

\section{Тарасюк Інна}

Волинський національний університет імені Лесі Українки

м. Луцьк, Україна

tarasiuk.inna@vnu.edu.ua

ORCID https://orcid.org/0000-0002-6026-3545

Мета. Сучасний політичний та суспільний розвиток актуалізує значення мови в контексті національної, культурної та соціальної ідентичності особистості. Особливого значення питання мови та іï функцій набуває в руслі успішної інтеграції мігрантів у іншомовному середовищі. Згідно з актуальними дослідженнями та опитуваннями населення в мультикультурних суспільствах, мові належить вирішальне значення в процесі інтеграції, а відтак сприяє успішній акультурації мігрантів. Метою статті $є$ здійснити огляд та проаналізувати наявні теорії мовної комунікації в контексті ідентичності особистості.

Методи. Для реалізації поставленої мети було використано базові теоретичні методи дослідження, а саме: аналіз, синтез, порівняння та узагальнення.

Результати. Дослідницький центр П'ю у Вашингтоні 2017 року оприлюднив результати опитування мігрантів по всьому світі, котрі засвідчують, що саме володіння мовою домінантної більшості $є$ надважливою передумовою, аби стати повноцінною частиною суспільства, бути інтегрованим та визнаним у ньому. Для поглибленого вивчення впливу мови на життя мігрантів у іншомовному середовищі було розроблено багато теорій з мовної комунікації. Одна з найбільш відомих теорій у контексті теми ідентичності $\epsilon$ теорія сочіальної ідентичності (SIT), за якою мова є ознакою, через яку особистість сигналізує свою соціальну ідентичність та належність до певної групи. Теорія етнолінгвістичної ідентичності (EIT) фокусує увагу на взаємозалежності між етнічною та мовною ідентичністю. В центрі уваги не лише мовленнєві дії, але й соціально-психологічні процеси, котрі лежать в основі міжкультурної комунікації. У центрі теорії комунікативної адаптації $(C A T)$ - соціально-психологічні фактори, що впливають на процес комунікації між різними, несхожими мовцями. В процесі такої комунікації відбувається усунення мовленнєвих відмінностей або ж навпаки наголошення на них (приміром через діалект або соціолект).

ISSN 2308-3743 (Online), ISSN 2227-1376 (Print)

(C) Тарасюк I., 2021. Ця стаття відкритого доступу на умовах CC BY-NC 4.0 
Висновки. В контексті акультурації мові належить беззаперечно важлива функція, адже завдяки їй відбувається обмін інформацією про належність до тієї чи тієї групи. Діалекти та акценти надають інформацію про регіональне походження. Через соціолекти мігранти ідентифікують себе 3 певними соціальними групами. Знання мови домінантної більшості відкриває додаткові перспективи для навчання та праці, а знання мови свого етносу дає можливість не втрачати зв'язків зі своєю етнічною спільнотою. Це і $є$ основним принципом інтеграції, а відтак і успішної акультурації. Отримані висновки та узагальнення будуть використані нами в емпіричному дослідженні психології акультурації іноземних студентів до іншомовного середовища.

Ключові слова: мультикультурне суспільство, теорія мовної комунікації, соціальна ідентичність, етнолінгвістична ідентичність, комунікативна адаптація.

\section{Tarasiuk Inna. The role of language within the context of migrants' identity and acculturation.}

Purpose. Current political and social development underscores the importance of language in the context of the national, cultural, and social identity of an individual. Notably, the matter of language and its functions becomes more prominent within the framework of effective integration of migrants into a foreign language environment. According to recent research and population surveys in multicultural societies, language is a critical aspect of integration. Therefore, it facilitates migrants' acculturation. The purpose of the article is to review and analyze existing theories of linguistic communication in the context of personal identity.

Method. To reach the declared objective, basic methods of theoretical research have been utilized, namely analysis, synthesis, comparison, and generalization.

Results. In 2017, the Pew Research Center in Washington published the results of a worldwide survey, featuring migrants as central respondents. The study shows that mastering the language of the dominant majority is a prerequisite for becoming an integral part of society. To examine the impact of language on the lives of migrants in a foreign language environment, numerous theories on language communication have been developed. One of the most renowned theories regarding the phenomenon of identity is the social identity theory (SIT), which considers language a sign a person utilizes to indicate their social identity and affiliation to a certain group. Ethnolinguistic identity theory (EIT) highlights the interdependence between ethnic and linguistic identities. The emphasis is put not only on speech actions but also on the socio-psychological processes that underlie intercultural communication. Socio-psychological factors that influence the process of communication between different speakers constitute the subject matter of the communication accommodation theory $(C A T)$. In the process of such communication, elimination of speech differences or, conversely, their accentuation occurs (i.e. through a dialect or sociolect).

Conclusions. In the context of acculturation, language functions as a medium for the exchange of information regarding affiliation with a particular social group. 
Furthermore, dialects and accents indicate the peculiarities of one's regional origin. Migrants use dialects and accents to identify themselves with certain social groups. Knowledge of the language of the dominant majority opens up additional prospects for study and work, whereas knowledge of the language of one's ethnic group allows maintaining contacts with their ethnic community. This is the core principle of integration and consequently effective acculturation. The conclusions and generalizations obtained are to be used in an empirical study concerning the psychology of acculturation of foreign students to a foreign language environment.

Keywords: multicultural society, theory of language communication, social identity, ethnolinguistic identity, communicative adaptation.

\section{Тарасюк Инна. Роль языка в контексте идентичности и аккультурации мигрантов.}

Цель. Современное политическое и общественное развитие актуализирует значение языка в контексте национальной, культурной и социальной идентичности личности. Особое значение вопрос языка и его функций приобретает в русле успешной интеграции мигрантов в иноязычной среде. Согласно актуальным исследованиям и опросам населения в мультикультурных обществах, языку принадлежит решающее значение в процессе интеграции, и таким образом способствует успешной аккультурации мигрантов. Целью статьи является осуществить обзор и проанализировать существующие теории языковой коммуникации в контексте идентичности личности.

Методы. Для реализации поставленной цели были использованы базовые теоретические методы исследования, а именно: анализ, синтез, сравнение и обобщение.

Результаты. Исследовательский центр Пью в Вашингтоне в 2017 году обнародовал результаты опроса мигрантов по всему миру, которые подтверждают, что именно владение языком доминантного большинства является важным условием, чтобы стать полноценной частью общества, быть интегрированным и признанным в нем. Для углубленного изучения влияния языка на жизнь мигрантов в иноязычной среде было разработано много теорий по языковой коммуникации. Одна из наиболее известных теорий в контексте темы идентичности является теория социальной идентичности (SIT), исходя из которой, язык является признаком, через который личность сигнализирует свою социальную идентичность и принадлежность к определенной группе. Теория этнолингвистической идентичности (EIT) фокусирует внимание на взаимозависимости между этнической и языковой идентичностью. В центре внимания не только речевые действия, но и социально-психологические процессы, лежащие в основе межкультурной коммуникации. В центре теории коммуникативной адаптации (САT) - социально-психологические факторы, влияющие на процесс коммуникации между разными, непохожими собеседниками. В процессе такой коммуникации происходит устранение речевых различий или же наоборот акцентирование на них (например, через диалект или социолект). 
Выводы. В контексте аккультурации языку принадлежит неопровержимо важная функция, ведь благодаря ей происходит обмен информацией о принадлежности к той или иной группе. Диалекты и акценты предоставляют информацию о региональном происхождении. Через социолекты мигранты идентифицируют себя с определенными социальными группами. Знание языка доминантного большинства открывает дополнительные перспективы для учебы и труда, а знание языка своего этноса дает возможность не терять связей со своей этнической общностью. Это и является основным принципом интеграции, а следовательно и успешной аккультурации. Полученные выводы и обобщения будут использованы нами в эмпирическом исследовании психологии аккультурации иностранных студентов к иноязычной среды.

Ключевые слова: мультикультурное общество, теория речевой коммуникации, социальная идентичность, этнолингвистическая идентичность, коммуникативная адаптация.

Вступ. Мова - це потужний ресурс, що виражає сутність особистості, формує ¥іi національну ідентичність, світогляд та вимальовує винятково індивідуальну картину світу.

Сучасний політичний та суспільний розвиток вносить свої корективи у життя багатьох людей, спонукає до отримання освіти чи роботи або влаштування особистого життя за кордоном. За цих обставин мова в контексті національної, культурної та соціальної ідентичності особистості набуває іншого відтінку як у науковому, так i практичному значенні. Саме мова $\epsilon$ першоджерелом черпання інформації про нове соціокультурне оточення, уклад життя, традиції, норми поведінки тощо. Без заперечення можна стверджувати, що мова - це не лише одна 3 надважливих складових об'ємного та тривалого процесу акультурації особистості в іншомовному, мультикультурному середовищі, але й запорука пї успішної інтеграції.

Метою статті $є$ продемонструвати роль мови в міжкультурному спілкуванні особистості мігранта у взаємодії 3 домінантною більшістю. Доречним вважаємо також навести приклади найбільш відомих теорій мовної комунікації, що $є$ дотичними до контексту ідентичності та акультурації.

Методи та процедура дослідження. Для цього були використані базові теоретичні методи дослідження, а саме: аналіз, синтез, порівняння та узагальнення.

Обговорення результатів. Дослідницький центр П'ю у Вашингтоні, котрий надає інформацію про соціальні проблеми, громадську думку і демографічні тенденції, які формуються в США і 
світі, а також проводить опитування громадської думки, демографічні дослідження, контент-аналіз та інші соціальні дослідження, надає результати опитування мігрантів по всьому світі, котрі засвідчують, що саме володіння мовою домінантної більшості $\epsilon$ надважливою передумовою, аби стати повноцінною частиною суспільства, бути інтегрованим та визнаним у ньому (Pew Research Center, 2017).

Візьмемо для прикладу Німеччину, як одну 3 найбільш мультикультурних країн Європи. Державну мову, німецьку, на урядовому рівні називають ключем до інтеграції (www.bmi.bund.de). В Німеччині забезпечення вивчення німецької мови знаходиться у площині відповідальності Федерального відомства 3 питань міграції та біженців (BAMF). На їхньому сайті знаходимо таку інформацію: «Якщо Ви хочете жити в Німеччині, Вам слід вчити німецьку мову. Це важливо для пошуку роботи і заповнення формулярів чи резюме, коли потрібно підтримати Ваших дітей у школі або ж познайомитися 3 новими людьми. Окрім того, Вам слід знати деякі факти про Німеччину, наприклад про іiі історію, культуру та законодавство» (www.bamf.de). Відповідно мігрантам забезпечують участь у так званих інтеграційних курсах (приблизно 600 академічних годин), на яких вивчається мова до рівня В1 згідно із Загальноєвропейськими Рекомендаціями 3 мовної освіти. Такі мовні курси доповнюються тематичними знаннями про німецьке законодавство, історію, культуру, важливі цінності, приміром свобода віросповідання, толерантність та рівність прав.

На інтеграційних курсах вивчення мови прирівнюється до самого процесу інтеграції і після його успішного закінчення підтверджується відповідним сертифікатом. Взагалі інтеграція - це комплексний, динамічний процес, що пришвидшується завдяки мові. Здебільшого інтеграцію розглядаємо як стратегію акультурації та як процес взаємодії домінантної більшості й етнічних меншин у різних аспектах, таких як цінності, норми, культурні та соціальні особливості. Особливе місце в інтеграційному процесі посідає питання ідентичності особистості та питання «хто я?» і «хто це вирішує?». Відповідь на ці запитання формується в результаті взаємодії 3 домінантним суспільством, наприклад через переймання соціальних ролей у сім'ї та професійній діяльності або ж належності до певної групи, котра, з одного боку, детермінується через такі критерії як стать, вік або етнічна належність, а 3 іншого боку, 
обирається свідомо, приміром завдяки участі в певних об'єднаннях, гуртках чи секціях (спорт, музика тощо) (Benet-Martínez, Haritatos, 2005; Dück, 2014; Makarova, 2008; Schmid, 2006 та ін.).

У цьому контексті мові належить особливо важлива функція, адже завдяки їй відбувається обмін інформацією. Діалекти та акценти вказують на регіональне походження. Через соціолекти мігранти ідентифікують себе 3 певними соціальними групами. Знання мови домінантної більшості відкриває додаткові перспективи для навчання та праці, а знання мови свого етносу дає можливість не втрачати зв'язків зі своєю етнічною спільнотою. Це і $є$ чи не основним принципом інтеграції, а відтак і успішної акультурації (Berry, 2003; Berry, Phinney, Sam, Vedder, 2006; Cato Bakk, 2011; Naglo, 2007 та ін.).

Мова як предмет дослідження традиційно знаходиться у площині лінгвістики (Spolsky, 2004). Ідентичність та акультурація - категорії, що розглядається у психології під різними кутами, приміром 3 точки зору вікової психології, психології особистості або ж соціальної психології. Оскільки соціальні функції мови в контексті ідентичності та акультурації в багатомовному середовищі вкрай важливі, безумовно аспекти вивчення та використання мови набувають міждисциплінарного характеру. Результати цих досліджень можуть бути інтегровані у питаннях врегулювання життя населення в мультикультурному суспільстві.

Мова завжди посідала вкрай важливе значення, тому існує багато теорій мовної комунікації. Одна 3 найбільш відомих теорій у контексті теми ідентичності є теорія соціальної ідентичності (SIT; Tajfel \& Turner, 1979). За вченими Г. Теджфел та Дж. Тернер соціальна ідентичність визначається як частина Я-концепції, яка формується під впливом знання, усвідомлення про належність до певної соціальної групи (соціальних груп) та емоційного зв'язку 3 нею. Групи утворюються на основі соціальних категорій. Відповідно ті чи ті ознаки особистості визначають її належність до певної групи. Ці ознаки можуть бути більш або менш чітко виражені, змінюватися або бути сталими. У той час як належність до таких категорій як стать та етнос $є$ стабільною, існують категорії, які людина може за бажанням змінювати, приміром бути частиною групи музикантів, спортсменів, вегетаріанців тощо. Через порівняння та категоризацію 
людина підпорядковується соціальному середовищу i $\epsilon$ вмотивованою сформувати власний позитивний образ (Naglo, 2007).

Також мова $є$ ознакою, через яку особистість сигналізує свою соціальну ідентичність та належність до певної групи. Мовна ознака істотно відрізняється від уже згаданих ознак. 3 одного боку, мова не $\epsilon$ такою сталою як, наприклад, етнічна належність. Особистість може розмовляти декількома мовами на різному рівні або ж втратити навички говоріння. Водночас багатомовність у будь якому разі дозволяє ій входити до більш ніж однієї групи. Вивчення кожної наступної мови вимагає часу й особистісного ресурсу та залежить від екстралінгвальних чинників, таких як вік, умови навчання тощо. Також важливо, щоб рівень володіння мовою відповідав вимогам входження в ту чи ту групу. Окрім того, мова може бути не лише ознакою певної мовної спільноти, а також і маркером соціальної ідентичності, як приміром релігійна чи ідентична належність. Так арабська мова та іврит часто асоціюються з релігіями іслам та юдаїзм.

3 теорії Г. Теджфела та Дж. Тернера можна зробити висновок, що мова відіграє значущу функцію у процесі інтеграції. Мовна компетенція не носія мови може бути категорійною ознакою для носія мови. Відтак не залежно від того, наскільки добре він володіє мовою домінуючого суспільства, для носіїв мови він залишатиметься представником іншої етнічної групи. 3 певною імовірністю можна стверджувати, що саме мовний аспект впливає на ступінь прийняття мігранта в суспільство домінуючої більшості. 3 точки зору етнічної меншини прагнення вивчити мову домінантної більшості може бути засуджено та розглядатися як бажання відділитися від своєї етнічної групи. А отже, мовний фактор подекуди може стати причиною конфлікту та мати негативі наслідки для представників двох або більше соціальних етносів (Gallois, Ogay, Giles, 2005).

Теорія етнолінгвістичної ідентичності (EIT; Giles, \& Johnson, 1987) базується на засадах теорії соціальної ідентичності, але фокусує увагу на взаємозалежності між етнічною та мовною ідентичністю. Теорія етнолінгвістичної ідентичності має міждисциплінарний характер та пропонує роз'яснення різним стратегіям, що застосовуються мовцями у міжетнічній взаємодії. В центрі уваги не лише мовленнєві дії, але й соціально-психологічні процеси, котрі лежать в основі міжкультурної комунікації. Припускається, що люди інтерпретують комунікативні ситуації як міжетнічну комунікацію і на 
використання мови впливає ситуація власної етнічної ідентичності порівняно з етнічною ідентичністю співрозмовника (Giles, Johnson, 1987). У цьому контексті мова розглядається у вимірі міжгрупового порівняння, іншими словами - як очевидна ознака ідентифікації 3 етнічною групою, яка свідомо використовується в інтеракції 3 представниками інших етнічних груп. Відповідно до цієї теорії, існують різні соціальні фактори (приміром прийняття ієрархії між своєю та чужою етнічною групою, різноманіття власної групи та мови, межі етнічної групи), які впливають на те, в якій формі окремі представники групи виражають свою етнічну ідентичність у мові і які стратегії для цього обирають.

Теорія етнолінгвістичної ідентичності також припускає, що етнічні мови можуть бути джерелом позитивної соціальної ідентичності та благополуччя людини. Використання рідної мови може стати захистом при невизначеності, страху смерті та загроз для самооцінки й контролю. Це особливо стосується етнічних меншин та груп іммігрантів (Giles, Johnson, 1987).

Ця думка була більш підсилена мовним контекстом та втілена в теорію комунікативної адаптації (САТ). У центрі теорії - соціальнопсихологічні фактори, що впливають на процес комунікації між різними, несхожими мовцями. В процесі такої комунікації відбувається усунення мовленнєвих відмінностей або ж навпаки наголошення на них (приміром через діалект або соціолект) (Gallois, Giles, 2015).

Автор теорії Говард Джайлз стверджує, що при взаємодії люди корегують своє мовлення, тембр голосу, жести, щоб налаштувати свого співрозмовника на бесіду (Turner, Lynn, West, 2010).

Ця теорія стосується передовсім зв'язків між мовою, контекстом та ідентичністю. Теорія сфокусована на міжгрупових та міжособистісних факторах, що призводять до адаптації, а також i способах, у яких макро- та мікроконтекст проблеми впливає на комунікативну поведінку (Gallois, Ogay, Giles,2005).

Теорія комунікативної адаптації описує два основних процеси адаптації: конвергенцію та дивергенцію. Конвергенція - це стратегія, завдяки якій індивіди пристосовуються до комунікативної поведінки один одного для того, щоб зменшити соціальні відмінності (Giles, Smith, 1979). 
Це може відбуватися за допомогою різних особливостей комунікації, наприклад, мови, вимови, паузи, тембру й темпу мовлення, невербальної комунікації. Конвергенція використовується на основі уявлень про інших людей або ж на основі спостережень, орієнтованих на сім'ю та оточення. Симпатія та авторитет також сприяють зближенню мовців. Коли співрозмовник коригує своє мовлення і невербальну поведінку для того, щоб сподобатися, і це так само подобається співрозмовнику, то їхнє спілкування може мати позитивний ефект. Тобто, коли конвергенція сприймається позитивно, це може підсилювати прихильність обох учасників комунікації один до одного. Саме тому можна стверджувати, що конвергенція відображає прагнення індивіда до соціального схвалення з боку свого співрозмовника. (Giles, Coupland, Coupland, 1991).

Конвергенція також збільшує ефективність комунікації, яка так само знижує невизначеність, міжособистісне занепокоєння і збільшує взаєморозуміння.

На противагу конвергенції, дивергенція, як лінгвістична стратегія, вказує на соціальні відмінності між особою та іiі співрозмовником.

Це, власне, відображає бажання групи підкреслити ㄲï самобутність у позитивному контексті. Це відбувається тоді, коли індивід сприймає процес взаємодії як міжгруповий, а не індивідуальний. Враховуючи той факт, що комунікативні функції $€$ основним критерієм належності до групи, дивергенція може розглядатися як одна 3 важливих тактик відображення цінності самобутності однієї групи на противагу іншій, що й допомагає підтримувати позитивний імідж групи для зміцнення своєї соціальної ідентичності (Giles, Ogay, 2007).

Висновки i перспективи. В контексті акультурації мові належить беззаперечно важлива функція, адже завдяки їй відбувається обмін інформацією про належність до тієї чи тієї групи. Діалекти та акценти надають інформацію про регіональне походження. Через соціолекти мігранти ідентифікують себе 3 певними соціальними групами. Знання мови домінантної більшості відкриває додаткові перспективи для навчання та праці, а знання мови свого етносу надає можливість не втрачати зв'язків зі своєю етнічною спільнотою. Це і $є$ серед основних принципів інтеграції, а 
відтак і успішної акультурації. Отримані висновки та узагальнення будуть використані нами в емпіричному дослідженні психології акультурації іноземних студентів до іншомовного середовища.

\section{References}

1. Adler P. (1997). Beyond cultural identity: reflections on cultural and multicultural man. Cultural learning: Concepts, application and research. R. W. Bristian (Ed.), 24-41. Honolulu.

2. BAMF (n.d.) Retrived from http://www.bamf.de/DE/Willkommen/ DeutschLernen/Integrationskurse/integratioskurse-node.html

3. Benet-Martínez, V., \& Haritatos, J. (2005). Bicultural Identity Integration (BII): Components and Psychosocial Antecedents. Journal of Personality, 73(4), 1015-1050.

4. Berry, J. W. (2003). Conceptual approaches to acculturation. Acculturation: Advances in theory, measurement, and applied research, 17-37. Washington, DC: APA.

5. Berry, J. W., Phinney, J. S., Sam, D. L., \& Vedder, P. (2006). Immigrant youth: Acculturation, identity, and adaptation. Applied Psychology: An International Review, 55(3), 303-332.

6. Berry, J. W. (2017). Introduction to mutual intercultural relations. Mutual intercultural relations, 1-33. Cambridge: CUP.

7. BMI (2017) Sprache ist der Schlüssel zur Integration. Retrived from https:// www.bmi.bund.de / Shared Docs / pressemitteilungen / DE / 2017 / 06 integrationskursverordnung.html

8. Cato Bakk, A. (2011). Eine soziolinguistische Untersuchung $\mathrm{zu}$ den Auswirkungen des Bilinguismus auf die Identität österreichischer Jugendlicher mit Migrationshintergrund. Zugriff über Universitätsbibliothek Universität Wien.

9. Dück, K. (2014). Zum Zusammenhang von Sprache und ethnischer Identität der zweiten Generation der Deutschen aus der ehemaligen Sowjetunion. Deutsche Sprache, 42(3), 261-274.

10. Gallois, Cyndy; Ogay, Tania; Giles, Howard (2005). Communication Accommodation Theory: A look Back and a Look Ahead. Theorizing About Intercultural Communication, 121-148. Thousand Oaks, CA: Sage.

11. Giles, H., \& Johnson, P. (1987). Ethnolinguistic identity theory: A social psychological approach to language maintenance. International Journal of the Sociology of Language, 68(1), 69-99.

12. Giles, Howard; Coupland, Joustine; Coupland, N. (1991). Accommodation Theory: Communication, Context, and Consequence. Contexts of Accommodation. New York, NY: Cambridge University Press.

13. Giles, Howard; Ogay, Tania (2007). «Communication Accommodation Theory». Explaining Communication: Contemporary Theories and Exemplars. Mahwah, NJ: Lawrence Erlbaum. 
14. Giles, Howard; Smith, Philip (1979). «Accommodation Theory: Optimal Levels of Convergence». Language and Social Psychology. Baltimore: Basil Blackwell.

15. Hoffmann-Nowotny, H.-J. (2000). Migration, soziale Ungleichheit und ethnische Konflikte. Migration, gesellschaftliche Differenzierung und Bildung, 157178. Opladen: Leske und Budrich.

16. Makarova, E. (2008). Akkulturation und kulturelle Identität. Eine empirische Studie unter Jugendlichen mit und ohne Migrationshintergrund in der Schweiz. Prisma, 8. Bern.

17. Naglo, K. (2007). Rollen von Sprache in Identitätsbildungsprozessen multilingualer Gesellschaften in Europa. Frankfurt: Lang.

18. Norris, S. (2007). The micropolitics of personal, national and ethnic identity. Discourse \& Society, 18(5), 653-674.

19. Pew Research Centre (2017). What It Takes to Truly Be 'One of Us'. U.S., Canada, Europe, Australia and Japan, publics say language matters more to national identity than birthplace. Retrived from https://www.pewglobal.org/ 2017/02/01/whatit-takes-to-truly-beone-of-us/

20. Schmid, W. (2006). Integriert ist, wer sich akzeptiert fühlt. Terra cognita, 9, $14-17$.

21. Spolsky, B. (2004). Language Policy. Cambridge: CUP.

22. Tajfel, H., \& Turner, J. C. (1979). An integrative theory of intergroup conflict. The Social Psychology of Intergroup Relations, 33-53. Monterey: Brooks/Cole.

23. Tamimi Sa'd, S. H. (2017). Foreign language learning and identity reconstruction: Learners' understanding of the intersections of the self, the other and power. CEPS Journal, 7(4), 13-36.

24. Turner, Lynn H.; West, Richard (2010). Communication Accommodation Theory. Introducing Communication Theory: Analysis and Application (4th ed.). New York, NY: McGraw-Hill.

25. Vedder, P., \& Virta, E. (2005). Language, ethnic identity, and the adaptation of Turkish immigrant youth in the Netherlands and Sweden. International Journal of Intercultural Relations, 29(3), 317-337.

Received: 01.03.2021

Accepted: 29.03.2021 